\title{
Stockholders' Holding Claim Class Actions under State Law after the Uniform Standards Act of 1998
}

\author{
Joshua D. Ratner $\dagger$
}

Consider a plaintiffs' attorney whose highly profitable practice consists of identifying companies whose stock prices fall dramatically and then filing class action lawsuits against these companies. This plaintiffs' attorney correctly assumes that many companies will settle these claims irrespective of their merits in order to avoid the expensive and intrusive discovery process and potentially damaging judgments. Such suits, where the plaintiffs' attorney brings an action merely to coerce a settlement out of the defendant, are known as strike suits.

In reaction to concerns about such strike suits, Congress passed the Private Securities Litigation Reform Act of $1995^{2}$ ("PSLRA"), which made it more difficult for plaintiffs' attorneys to file strike suits in federal court. In response, these attorneys began to file more actions in state courts. ${ }^{3}$ Congress, in turn, passed the Securities Litigation Uniform Standards Act of $1998^{4}$ ("Uniform Standards Act"), which stated that "[n]o covered class action based upon the statutory or common law of any State or subdivision thereof may be maintained in any State or Federal court by any private party alleging ... [fraud] ... in connection with the purchase or sale of a covered security." The Uniform Standards Act thus sought to allow companies to avail themselves fully of the protections the PSLRA provides against strike suits. Recently, however, plaintiffs' attorneys have struck again by exploit-

$\dagger$ B.A. 1999, Brandeis University; J.D. Candidate 2002, The University of Chicago.

1 See Black's Law Dictionary 1448 (West 7th ed 1999) (defining a strike suit as "[a] suit ... often based on no valid claim, brought either for nuisance value or as leverage to obtain a favorable or inflated settlement").

2 Pub L No 104-67, 109 Stat 737 (1995), codified at 15 USC $\$ \$ 77$ a et seq (1994 \& Supp 1995) (reforming federal securities litigation to reduce abusive litigation and coercive settlements).

3 Michael A. Perino, Fraud and Federalism: Preempting Private State Securities Fraud Causes of Action, 50 Stan L Rev 273,298-315 (1998) (suggesting that the increased filings in state court after the PSLRA plausibly reflected a shift of the weaker causes of action to state court to avoid the PSLRA).

4 Pub L No 105-353, 112 Stat 3227 (1998), codified in various sections of title 15 (1994 \& Supp 1998) (passed "in order to prevent certain State private securities class action lawsuits alleging fraud from being used to frustrate the objectives of the Private Securities Litigation Reform Act of 1995").

515 USC $\$ 77 \mathrm{p}(\mathrm{b})$. See note 90 for a discussion of the meanings of "covered security" and "covered class action" under the Uniform Standards Act. 
ing a loophole in the Uniform Standards Act that has allowed them to bring securities fraud class actions in state court. They have done so by reviving the little-used state common law action of a "holding claim." A holding claim is an action by a stockholder alleging that the defendant wrongfully induced the plaintiff to continue holding her stock. It asserts damages of the diminished value of the stockholder's stock caused by the defendant's misrepresentation. ${ }^{6}$ This Comment argues that courts should close this loophole in order to allow the PSLRA and the Uniform Standards Act to fulfill completely Congress's intent to minimize strike suits.

In Part I, this Comment traces the history of securities fraud claims, including holding claims, under both state and federal law prior to the PSLRA. Part II discusses the ways in which the PSLRA and the Uniform Standards Act changed the balance of power between the federal government and the states. This Part then examines the revival of holding claims in the aftermath of the Uniform Standards Act. Finally, Part III argues that holding claim class actions should be viewed as obstructing the purpose of the Uniform Standards Act and that such claims should be viewed as implicitly preempted by these statutes. In so doing, this Part examines the deterrent and compensatory effects of preemption of holding claim class actions.

\section{FEDERAL/State RELATIONSHIP IN CASES AlLEGING SECURITIES FRAUD PRIOR TO 1995}

This Part discusses the traditional existence of both state and federal private causes of action for securities fraud. In particular, this Part examines the history of holding claims in state and federal courts.

\section{A. State Regulation of Securities Fraud}

While companies' securities are often traded without any wrongdoing, for centuries governments have recognized that problems of fraud inherently exist in securities markets. ${ }^{8}$ States traditionally have regulated securities fraud through common law torts such as fraud and negligent misrepresentation, 'through derivative actions by stock-

6 See text accompanying notes 23-30.

7 The word "preempted," as used in this Comment, means preempted in the constitutional sense of a federal law supplanting an inconsistent state action.

8 Louis Loss and Joel Seligman, Fundamentals of Securities Regulation 1-3 (Little, Brown 3d ed 1995) (discussing the history of securities regulation in England and the United States).

9 See Michael G. Dailey, Comment, Preemption of State Court Class Action Claims for Securities Fraud: Should Federal Law Trump?, 67 U Cin L Rev 587, 602-06 (1999) (noting the use of common law claims for fraud and negligent misrepresentation to bring securities fraud cases in state courts). 
holders suing on behalf of the corporation itself, ${ }^{10}$ and through statutes called blue sky laws."

\section{Common law causes of action.}

States allow various common law actions for securities fraud. ${ }^{12}$ These actions are often filed as either fraud ${ }^{13}$ or negligent misrepresentation $^{14}$ claims. States' requirements differ from federal requirements, with some requirements being stricter than federal law ${ }^{15}$ and others being more lax and providing broader remedies. ${ }^{16}$ Importantly, in

10 See Jeffrey S. Facter, Fashioning a Coherent Demand Rule for Derivative Litigation in California, 40 Santa Clara L Rev 379, 381-82 (2000) (noting that due to the passage of the Uniform Standards Act, plaintiff-shareholders wishing to bring actions in state court will be more likely to file derivative actions).

11 The statutes are commonly called "blue sky" laws because they serve to protect the public from those who may attempt to sell them the blue sky. See Dailey, Comment, 67 U Cin L Rev at $600-01$ (cited in note 9) (noting that blue sky laws all regulate in-state securities distribution and broker-dealer activity).

12 See Richard W. Painter, Responding to a False Alarm: Federal Preemption of State Securities Fraud Causes of Action, 84 Cornell L Rev 1, 20 (1998) ("Private rights of action, at common law and in equity, for persons injured in securities transactions preceded state statutes regulating the sale of securities, and many of those remedies still exist.").

13 The prerequisites for a common law securities fraud claim differ from state to state. The essential elements under California law provide an example: a misrepresentation, knowledge by the defendant of its falsity, the defendant's intent to induce a particular action by a particular person, actual and justifiable reliance, and resulting damage. See Sara Beth Brody and Ted F. Angus, Securities Litigation in State Court, in Jay B. Kasner and Bruce G. Vanyo, Securities Litigation 1998 413, 416 (PLI 1998). Alternatively, such claims are labeled causes of action for deceit. See Painter, 84 Cornell L Rev at 21 n 99 (cited in note 12) (noting the requirements of a cause of action for deceit).

14 The elements of negligent misrepresentation also differ slightly from state to state. Again, the essential elements under California law are typical: a misrepresentation, no reasonable grounds for the defendant to believe the statement to be true, an intent to induce a particular action by a particular party, actual and justifiable reliance, and resulting damage. See Brody and Angus, Securities Litigation in State Court at 418 (cited in note 13). Such causes of action are alternatively called causes of action for equitable fraud. See Painter, 84 Cornell L Rev at 21 (cited in note 12) (noting that such a cause of action does not require proof of scienter).

15 New Jersey requires that the plaintiff show the defendant had actual knowledge of the falsity to obtain legal damages while the federal standard is recklessness. See Bonnco Petrol, Inc $v$ Epstein, 115 NJ 599, 560 A2d 655, 660 (1989) (noting that to recover damages for legal fraud the defendant must have knowledge). See also note 73 (noting that most federal courts adhere to the view that scienter may be proved by showing recklessness even after the PSLRA). Furthermore, while most states along with the federal courts merely require the burden of proof of a preponderance of the evidence, New York and Pennsylvania require clear and convincing evidence. See Bruce G. Vanyo, et al, Securities Class Action Litigation in State Courts, in Jay B. Kasner and Bruce G. Vanyo, Securities Litigation 1996 207, 257 (PLI 1996).

16 The more lax requirements of state law include the availability of a cause of action for negligent misrepresentation, while under federal law, the defendant must have a mental state greater than negligence to be liable. See Ernst \& Ernst v Hochfelder, 425 US 185, 193-94 n 12 (1976) (holding that liability under Section 10(b) of the Securities Exchange Act of 1934 and SEC Rule 10b-5 requires "a mental state embracing intent to deceive, manipulate, or defraud"); Vanyo, et al, Class Action Litigation at 259-76 (cited in note 15) (discussing negligent misrepresentation claims in various states). Additionally, states allow the broader remedy of punitive 
10b-5 securities fraud actions, ${ }^{17}$ federal courts allow a plaintiff to use the fraud-on-the-market theory ${ }^{18}$ as a rebuttable presumption of reliance, instead of having to show actual reliance. State courts, however, generally require securities fraud plaintiffs to show actual reliance." Due to the difficulty of showing actual reliance in class action form, Delaware courts have twice refused to allow class actions claiming common law securities fraud. ${ }^{20}$ Other states, however, have allowed common law securities fraud class actions even though they require actual reliance by each class member, ${ }^{21}$ and in non-securities litigation,

damages unavailable under federal securities laws. Compare Byrnes v Faulkner, Dawkins \& Sullivan, $550 \mathrm{~F} 2 \mathrm{~d} 1303,1313$ (2d Cir 1977) (noting that 10b-5 claims are limited to actual damages because the rule was promulgated under the 1934 Act, which denies recovery to a plaintiff for any amount "in excess of his actual damages on account of the act complained"), quoting 15 USC $\$ 78 b b(a)$ (Supp 1975), and Hill York Corp v American International Franchises, Inc, 448 F2d 680,697 (5th Cir 1971) (holding no punitive damages available under Section 12 of the 1933 Act), with Pittsburgh Live, Inc v Servov, 615 A2d 438, 442 (Pa 1992) (allowing punitive damages where there are "acts of malice, vindictiveness and a wholly wanton disregard of the rights of others"). Additionally, some states have longer statutes of limitations than the federal statute of limitations, and unlike the federal statute of limitations, which requires that the suit be brought within three years of the wrong, states generally do not begin the limitations period until the plaintiff discovers the fraud. See Lampf, Pleva, Lipkind, Prupis \& Petigrow v Gilbertson, 501 US 350 (1991) (setting the federal statute of limitations); Vanyo, et al, Class Action Litigation at 25356 (cited in note 15) (comparing various states' statutes of limitations).

17 See Part I.B for a discussion of $10 \mathrm{~b}-5$ actions.

18 Under the fraud-on-the-market theory, in open and well-developed markets such as national exchanges, the price of a security reflects all known material information whether the information is true or false. Assuming that the investor believes the price reflects its value, the investor who purchases or sells a security when false information is affecting the security's price thus indirectly relies on the misrepresentation. See James I. Jaconette, Note, The Fraud-On-TheMarket Theory in State Law Securities-Fraud Suits: Mirkin v. Wasserman and an Examination of Market Reliance Principles in the Common Law of Deceit, 46 Hastings L J 1967, 1968-69 (1995) (describing the fraud-on-the-market theory). In Basic, Inc v Levinson, 485 US 224, 245-47 (1988), the United States Supreme Court held that the fraud-on-the-market theory applies to $10 \mathrm{~b}-5 \mathrm{fed}$ eral securities fraud actions as a rebuttable presumption that the plaintiffs relied on the misrepresentation, and the purchaser or seller need not prove that she individually relied on the misrepresentation in deciding whether to purchase or sell her stock.

19 See Mirkin v Wasserman, 5 Cal 4th 1082, 858 P2d 568, 584 (1993) (ruling that "fraud-onthe-market theory" should not be extended to state court common law actions and instead requiring a showing of actual reliance); Gaffin v Teledyne, Inc, 611 A2d 467, 474-75 (Del 1992) (same under Delaware common law fraud); Kahler v E.F. Hutton \& Co, 558 S2d 144, 145 (Fla App 1990) (same under Florida common law fraud). But see Jaconette, Note, 46 Hastings $L J$ at 1996-2002, 2013 (cited in note 18) (arguing that state courts should adopt the fraud-on-themarket theory).

20 See Gaffin, 611 A2d at 474 (affirming denial of class certification in common law fraud claim based on corporation's stock repurchase due to individual questions of reliance); Glosser $v$ Cellcor Inc, [1995 Tr. Binder] Fed Secur L Rep (CCH) Il 98,708 at 92,302-03 (Del Ch 1995) (denying class certification for common law claims in securities fraud case because of necessity of proving individual reliance).

21 A New York state court and an Iowa state court have certified common law securities fraud class actions. See Pruitt v Rockefeller Center Properties, Inc, 167 AD2d 14, 574 NYS2d 672, 676 (1991) (affirming class certification in securities fraud action despite individual questions of reliance, where misrepresentations made to each plaintiff were identical); Kramersmeier $v$ R.G. Dickinson \& Co, 440 NW2d 873, 879 (Iowa 1989) (same). 
most states have allowed common law fraud class actions even in the face of the actual reliance requirement. ${ }^{22}$

One substantial difference between state and federal law is that a few states have allowed suits under the common law claiming damages on a theory that the defendant fraudulently induced the plaintiff to hold her stock. . $^{23}$ Before passage of the PSLRA in 1995, Massachusetts $^{24}$ and New York ${ }^{25}$ had recognized such "holding claims," and Wis$\operatorname{consin}^{26}$ and New Hampshire ${ }^{27}$ had allowed causes of action for holding in similar contexts. Furthermore, a federal district court interpreting New Jersey law predicted that New Jersey would recognize a holding cause of action. ${ }^{28}$ The damages claimed in these state holding claims flowed from the fact that the price of the stock at the time of suit was lower than at the time of the misrepresentation, so that if the plaintiff currently chose to sell, she would receive less money for the stock.

22 See Vanyo, et al, Class Action Litigation at 357-61 (cited in note 15) (collecting cases from various states and concluding that the great majority of courts allow class actions in spite of the individual reliance requirement). These courts generally apply the same reasoning as the federal courts granting class certification, pointing to the judicial economy of a class action and the possibility of alternative proceedings for dealing with individual issues. Id at 361.

23 Federal courts do not allow holding claims. See Part I.B.2.

24 Fottler v Moseley, 179 Mass 295, 60 NE 788, 789 (1901) (allowing a stockholder to bring a cause of action against the defendant who fraudulently induced plaintiff to refrain from selling his stock). This case uses a but for causation standard. See id. See also David v Belmont, 291 Mass 450, 197 NE 83, 85-86 (1935) (ruling on an issue regarding damages for a holder of stock). Massachusetts may have required the plaintiff to allege an additional element-a preparatory act showing that the plaintiff would have sold the stock but for the misrepresentation. See Fottler, $60 \mathrm{NE}$ at 788 (noting that the plaintiff had withdrawn his sell order because of the defendant's misrepresentation). But see David, $197 \mathrm{NE}$ at 84-86 (upholding a charge by the trial judge in a damages case, which did not include any mention of a preparatory act).

25 Continental Insurance Co v Mercadante, 225 NYS 488, 222 AD 181, 183-84 (1927) (holding that where the defendant induced the plaintiff to keep his stock, which otherwise he may have sold, the plaintiff can maintain a cause of action). This case did not require that the plaintiff prove he would have sold but for the fraud and held that it was adequate for the plaintiff to prove that "the fraud actually accomplished the result it was intended to bring about." Id.

26 See Seideman $v$ Sheboygan Loan \& Trust Co, 198 Wis 97, 223 NW 430, 433 (1929) (allowing a cause of action where a bondholder was induced into holding bonds).

27 See Brown-Wales Co v Barber, $88 \mathrm{NH} 103,184$ A 855, 859 (1936) (holding that a creditor can maintain a suit against a defendant for inducing the creditor to forebear action to collect the debt).

28 Gutman v Howard Savings Bank, 748 F Supp 254, 263-66 (D NJ 1990) (holding that the policy considerations militating against allowing holding claims are outweighed by the facts of the case, which involved direct dealings and noting that the New Jersey Supreme Court looks favorably towards novel common law claims). The Gutman court predicted that New York and New Jersey would not require the pleading of a preparatory act as a prerequisite to standing and granted standing to a plaintiff without such pleading. See id at 263,267. But see Chanoff $v$ United States Surgical Corp, 857 F Supp 1011, 1018 (D Conn 1994), affd 31 F3d 66 (2d Cir 1994) (finding that a holding claim is "too speculative to be actionable" under Connecticut law because damages are too speculative).

29 Gutman, 748 F Supp at 263-66; Continental Insurance Co, $222 \mathrm{AD}$ at 183-84; Fottler, 60 $\mathrm{NE}$ at 789 . But see Chanoff, $857 \mathrm{~F}$ Supp at 1018 (finding such a claim for damages too speculative). 
Importantly, all of the pre-1995 cases deciding whether states should allow holding claims involved personal dealings between the stockholder and the defendant.

\section{Derivative suits.}

Derivative suits resemble holding claims in that plaintiffstockholders may be able to bring derivative actions when there is a drop in the value of the corporation's stock, even when the plaintiff merely continues to hold stock. ${ }^{31}$ Unlike holding claims, however, derivative claims are brought on behalf of the corporation itself ${ }^{32}$ and allege that violation of duties owed by the corporation's officers or directors led to the drop in the stock price. ${ }^{33}$ For instance, the Delaware Supreme Court in Malone $v$ Brincat ${ }^{34}$ held that corporate officers' and directors' fiduciary duty of disclosure is breached whenever the officer or director knowingly disseminates false information that results in corporate injury or damage to an individual shareholder, whether or not there has been a request for shareholder action, ${ }^{35}$ and this breach can be the basis of a derivative action.

30 The Gutman court noted that the personal dealings between the plaintiff and defendant were a "critical feature" in allowing a cause of action because the case was more akin to an ordinary case of deceit than a securities cause of action. $748 \mathrm{~F} \mathrm{Supp}$ at 266 . There was, however, one known class action holding claim prior to 1995 , which did not implicate personal dealings. See Weinberger $v$ Kendrick, 698 F2d 61, 78 (2d Cir 1982) (approving a class settlement, which gave less damages to state law claims including a holding claim under New York law than for federal securities law claims in the same class action). The Weinberger court was not deciding whether to allow holding claims as a cause of action and did not comment on allowing holding claims in class action form, and instead it simply noted that New York allowed holding claims before analyzing the settlement. In this case, the court was asked merely to review the fairness of the settlement, and in so doing, expressed its view that holding claims were less valuable than the purchaser's claims under federal securities law. Id.

31 Generally, the plaintiff must be a holder of stock at the time of the alleged wrongful action in order to meet the requirements for bringing a derivative suit. See William A. Klein and John C. Coffee, Jr., Business Organization and Finance: Legal and Economic Principles 196-201 (Foundation 7th ed 2000) (discussing general types of procedural prerequisites for bringing derivative suits followed by many states, including being a shareholder who held stock contemporaneously at the time of the wrongful action, the demand rule, posting a "security for expenses" bond, and special pleading rules).

32 When a shareholder-plaintiff gains a recovery (either monetary or nonmonetary) in a derivative suit, the recovery accrues to the corporation. All shareholders are compensated by a recovery because if the recovery is greater in value to the corporation than the costs of the litigation, the value of each shareholder's equity will rise. For a general discussion. see id at 196 (discussing how in theory a shareholder brings a derivative suit on behalf of the corporation against those who have wronged the corporation).

33 See id at 148-68 (noting the prerequisites for finding breaches of the duty of care and the duty of loyalty).

34722 A2d 5 (Del 1998).

35 Id at 11, 14. But see Nicole M. Kim, Note, Malone v. Brincat: The Fiduciary Disclosure Duty of Corporate Directors under Delaware Law, 74 Wash L Rev 1151, 1179 (noting that Malone gives little guidance on the scope of its application).

36 Malone, 722 A2d at 14. 
In general, the law views a breach of duty, which hurts all shareholders' stock proportionately by causing a decrease in the market value of the corporation's stock, as injuring the corporation alone. An action to seek compensation for such a breach can therefore only be brought as a derivative action. ${ }^{37}$ By contrast, stockholder standing in a direct cause of action generally requires an allegation of injury that is direct or independent of the corporate harm. ${ }^{38}$ Consequently, holding claims may not be cognizable as nonderivative actions under state law if the plaintiff merely alleges an injury from the devaluation of held stock, which the plaintiff claims she would have sold. ${ }^{39}$

\section{State blue sky laws.}

Besides common law causes of action and derivative actions, every state regulates securities through statutes called blue sky laws, and each state's blue sky laws currently have statutory provisions penalizing those who use fraud to sell securities. ${ }^{41}$ Some states permit enforcement of their blue sky laws only by the state government with no private cause of action. ${ }^{42}$ In other states, private causes of action are allowed in addition to state government enforcement, but the statutory texts clearly limit the private actions to those who "purchase or sell" the securities. Even in Oregon, where the statute itself is unclear, it is

37 Kramer v Western Pacific Industries, Inc, 546 A2d 348, 353 (Del 1988) (stating that under Delaware law, "[a]ny devaluation of stock is shared collectively by all the shareholders, rather than independently by ... any ... individual shareholder," and such a claim is "entirely derivative in nature" and is not a direct or independent injury to the stockholder, which could be maintained as a private cause of action).

38 Id at 351.

39 See Kim, Note, 74 Wash L Rev at 1173 (cited in note 35) (arguing that a claim by holders of stock in Malone would only have been proper as a derivative action). For a similar situation regarding standing to bring a securities fraud claim under RICO, see Crocker v Federal Deposit Insurance Corp, 826 F2d 347, 350-52 (5th Cir 1987) (finding that a holding claim is too speculative to state an individual injury to shareholders apart from a diminution in the value of their stock, and that the claim should therefore be brought as a derivative action).

40 Kansas first passed a statute regulating securities in 1911, see Painter, 84 Cornell L Rev at 21 (cited in note 12) (noting that most blue sky laws preserve common law remedies in addition to statutory remedies), and currently every state has blue sky laws. See Richard W. Jennings, et al, Securities Regulation, Cases and Materials 107 (Foundation 8th ed 1998).

41 For a fifty state survey of civil liability provisions, or the lack thereof, see Charles G. Stinner, Note, Estoppel and in Pari Delicto Defenses to Civil Blue Sky Law Actions, 73 Cornell L Rev 448, 449-53 (1988).

42 For example, New York's Martin Act, NY Gen Bus Law § 352-c (McKinney 1996), does not give individuals a private cause of action. See CPC International Inc v McKesson Corp, 70 NY2d 268, 514 NE2d 116, 118 (1987) (holding no private cause of action is impliedly created under Section 352-c).

43 See, for example, California's blue sky laws. Cal Corp Code $\$ \S 25400,25500$ (West 1977) (creating a private cause of action against those who create false or misleading statements or appearance of active trading to induce a purchase or sale or to manipulate prices); id $\S \S 25401$, 25501 (creating a private cause of action against those who make untrue statements or omissions in connection with purchase or sale); id $\$ \S 25402,25502$ (creating a private cause of action 
unlikely that a court would permit a holding claim. ${ }^{44}$ Therefore, blue sky laws do not statutorily create a private cause of action for stockholders who are induced into holding stock because of a fraud or misrepresentation.

\section{B. Advent of Federal Regulation}

In the aftermath of the stock market crash of 1929 and resulting Great Depression, the federal government became involved in regulating securities. In so doing, the federal government acknowledged that securities fraud presented problems different from ordinary fraud and that the states had proved ineffective in regulating nationally traded securities on their own.

\section{Early federal securities statutes.}

In order to regulate securities more effectively, Congress passed the Securities Act of $1933^{47}$ ("1933 Act") and the Securities Exchange Act of $1934^{48}$ ("1934 Act"). While both acts reflected federal dissatisfaction with the states as regulators, each explicitly allowed concurrent securities regulation by the states.

against those who are connected with the issuer and purchase or sell stock based on information not available to the public).

44 Oregon's blue sky law, Or Rev Stat $\S 59.135$ (1999) (making it unlawful to defraud in connection with the conduct of a securities business), would appear not to be limited to causes of action in connection with the purchase or sale of a security and would possibly give an implied cause of action to holders of stock. However, the Oregon Supreme Court in Held v Product Manufacturing Co, 286 Or 67, $592 \mathrm{P} 2 \mathrm{~d} 1005,1007$ (1979), held that there are no implied causes of action under Section 59.135, and the Oregon statutes only expressly allowed causes of action by purchasers at the time the suit was filed, Or Rev Stat $\$ 59.115$ (1999). Oregon law was subsequently amended to allow causes of action by sellers as well. Or Rev Stat $\S 59.127$ (1999).

45 Steven A. Ramirez, Arbitration and Reform in Private Securities Litigation: Dealing with the Meritorious as well as the Frivolous, $40 \mathrm{Wm} \&$ Mary L Rev 1055, 1067 (1999) (noting that Congress and President Roosevelt passed the 1933 Act and the 1934 Act in order to renew investor confidence in the economic system).

46 See Painter, 84 Cornell L Rev at 23 (cited in note 12) (noting that states were ineffective as the sole regulators of nationally traded securities because of state securities commissioners' inability to extend their authority across state lines).

4748 Stat 74 (1933), codified as amended at 15 USC $\$ \S 77$ a et seq (1994) (requiring the registration and full disclosure of initial distributions of securities).

4848 Stat 881 (1934), codified as amended at 15 USC $\$ \S 78 \mathrm{a}$ et seq (1994) (providing for the regulation of the securities industry and requiring periodic disclosure for publicly held companies).

49 See Painter, 84 Cornell L Rev at 24-25 (cited in note 12) (noting that Section 18 of the 1933 Act did not affect the jurisdiction of state securities commissions and bestowed concurrent state and federal court jurisdiction; and that while the 1934 Act gave federal courts exclusive jurisdiction over claims under that Act, Section 28(a) specifically protected blue sky laws from federal preemption). For the 1933 Act's bestowing concurrent jurisdiction, see 15 USC $\$ 77 \mathrm{r}$; and for the 1934 Act's protection of state laws, see 15 USC $\S 78 \mathrm{bb}(\mathrm{a})$ ("[T] vided by this chapter shall be in addition to any and all other rights and remedies that may exist at law or in equity."). 
In the aftermath of the federal entrance into the securities regulatory arena, federal courts, as well as the Securities and Exchange Commission ("SEC"), began to acknowledge the important role of private suits as a method of supplementing government enforcement actions. ${ }^{\text {so }}$ Section 10 (b) of the 1934 Act empowered the SEC to enact rules and regulations regarding the use of manipulative and deceptive devices in relation to the purchase or sale of securities. ${ }^{51}$ The SEC promulgated SEC Rule 10b-5 ("10b-5") under the authority of this Section, and beginning in 1946, federal courts implied a private cause of action ${ }^{53}$ under $10 \mathrm{~b}-5$. Such an action could only be brought in federal court. ${ }^{54}$

\section{Holding claims under federal law.}

Federal courts have held since the 1952 case of Birnbaum $v$ Newport Steel Corp ${ }^{55}$ that only those induced into purchasing or selling a security have standing to bring a $10 \mathrm{~b}-5$ action. ${ }^{56}$ Affirming this rule in 1975, the United States Supreme Court in Blue Chip Stamps v Manor Drug Stores ${ }^{57}$ noted the problems associated with granting standing to nonpurchasers or nonsellers, including those bringing holding claims. In particular, the Court noted that even though the wording of Section 10(b) of the 1934 Act did not clearly express congressional intent as to the contours of the cause of action under $10 \mathrm{~b}-5,{ }^{58}$ the policy reasons

50 See Ramirez, $40 \mathrm{Wm}$ \& Mary L Rev at 1067 (cited in note 45) (noting that courts and the SEC saw private proceedings as an "essential supplement to the SEC's limited enforcement resources").

51 See Securities Exchange Act $\$ 10(\mathrm{~b})$, codified at 15 USC $\$ 78 \mathrm{j}(\mathrm{b})$.

5217 CFR § 240.10b-5 (2000). The rule states:

It shall be unlawful for any person ... [t]o employ any device, scheme, or artifice to defraud, [t]o make any untrue statement of a material fact or to omit to state a material fact necessary in order to make the statements made ... not misleading, or [t]o engage in any act, practice, or course of business which operates or would operate as a fraud or deceit upon any person, in connection with the purchase or sale of any security.

Id.

53 Affiliated Ute Citizens of Utah v United States, 406 US 128, 151-54 (1972) (emphasizing that the 1934 Act and 10b-5 should be read broadly); Superintendent of Insurance of New York $v$ Bankers Life \& Casualty Co, 404 US 6, 13 n 9 (1971) (confirming the existence of an implied private right of action); Kardon v National Gypsum Co,69 F Supp 512, 514 (E D Pa 1946) (implying a private right of action under $10 \mathrm{~b}-5$ ).

54 Title I of the 1934 Act states that federal district courts have exclusive jurisdiction over violations of the 1934 Act "or the rules and regulations thereunder, and of all suits in equity and actions at law brought to enforce any liability or duty created by this chapter or the rules and regulations thereunder." 15 USC § 78aa. 10b-5 was promulgated under section 10(b) of the 1934 Act, so federal courts have exclusive jurisdiction over such action. See notes 51-52 and accompanying text for a discussion of the promulgation of $10 \mathrm{~b}-5$.

55193 F2d 461 (2d Cir 1952).

56 Id at 464.

57421 US 723 (1975).

$58 \quad$ Id at 737. 
supporting a limitation to purchasers and sellers were strong. ${ }^{59}$ The Court found holding claims were especially prime candidates to cause strike suits because such claims would "turn largely on which oral version of a series of occurrences the jury may decide to credit, and [] no matter how improbable the allegations of the plaintiff, the case [would] be virtually impossible to dispose of prior to trial other than by settlement." ${ }^{, 60}$ The Court emphasized that unlike claims based on a purchase or a sale, transactions that are verifiable by documentation, those suits that do not meet the purchase or sale requirement are more likely to be strike suits because no matter how hard they are to prove at trial, "they are even more difficult to dispose of prior to trial."" This type of suit, therefore, would "encourage the least appealing ... use of the discovery rules" - as a tool solely for forcing settlements. ${ }^{62}$

In ruling that holders of stock cannot bring claims under federal law, the Court in Blue Chip Stamps noted the availability of causes of action in state court. In particular, the Court acknowledged that holders of stock frequently may be able to bring a derivative action on behalf of the corporation. ${ }^{63}$ Also, in a footnote, the Court stated that any disadvantage in refusing to allow standing to holders of stock and others "is attenuated to the extent that remedies are available to nonpurchasers and nonsellers under state law." ${ }^{\text {,4 }}$ In so noting, the Court seemed to leave open the possibility of holding claims in state court.

Thus, prior to 1995 , plaintiffs were able to plead state law actions for securities fraud even though the federal government regulated securities through the implied cause of action under 10b-5. Although the Supreme Court precluded plaintiffs from bringing holding claims in federal court, federal law did not foreclose bringing holding claims in state court instead.

\section{THE PSLRA AND THE UNIFORM STANDARDS ACT}

This Part analyzes the changes in private causes of action for securities fraud in federal and state courts resulting from the passage of the PSLRA and the Uniform Standards Act. In particular, this Part evaluates the legislative history of the Uniform Standards Act to evaluate the Act's purpose. This Part also analyzes the revival of state holding claims in the aftermath of the Act.

59 Id at $739-40$.

60 Id at 742.

61 Id, citing Blue Chip Stamps v Manor Drug Stores, 492 F2d 136, 147 n 9 (9th Cir 1973) (Hufstedler dissenting).

62 Blue Chip Stamps, 421 US at 741.

63 Id at 738.

64 Id at $738 \mathrm{n} 9$. 


\section{A. The PSLRA}

In recent decades, the federal judiciary has taken a more negative view of private securities suits, seeing them as "vexatious tool[s]" to force settlements of meritless claims, and accordingly has endorsed more restrictive approaches to such actions. ${ }^{65}$ In particular, the Supreme Court ruled that there is a relatively short statute of limitations for actions under Section 10(b), ${ }^{66}$ eliminated aiding and abetting liability under Section $10(\mathrm{~b}){ }^{67}$ and restricted the availability of rescission claims. ${ }^{68}$ In addition, federal district courts have been making it more difficult to plead a private securities cause of action effectively. ${ }^{69}$

In 1995, Congress followed the federal courts' trend and passed the PSLRA, which increased protections for companies against strike suits. $^{70}$ In enacting the PSLRA, "Congress made clear its belief that opportunistic trial lawyers were undermining the securities litigation

65 See Ramirez, 40 Wm \& Mary L Rev at 1068-72 (cited in note 45) (discussing the trend by the Supreme Court and lower federal courts to limit private securities actions). See Douglas M. Branson, Running the Gauntlet: A Description of the Arduous, and Now Often Fatal, Journey for Plaintiffs in Federal Securities Law Actions, 65 U Cin L Rev 3, 6 (1996) ("In forty federal securities law decisions, the Court decided thirty-two cases for defendants and, in almost every one, significantly narrowed the reach of federal securities laws.").

For a commentary on the problems associated with strike suits, see, for example, Janet Cooper Alexander, Do the Merits Matter? A Study of Settlements in Securities Class Actions, 43 Stan L Rev 497, 500 (1991) (arguing that lawsuits are filed very frequently against companies whose stock declines significantly, that most cases settle, and that settlements are not based upon merits but rather upon legal costs and other nonmerit factors). But see Joel Seligman, The Merits Do Matter: A Comment on Professor Grundfest's "Disimplying Private Rights of Action Under the Federal Securities Laws: The Commission's Authority," 108 Harv L Rev 438, 457 (1994) ("What has been most lacking in the legislative debate to date has been authentic data that provides empirical or theoretical support for particularized law revision. If there is a case for significant changes in the federal securities class action law, it simply has not been presented to date.").

66 See Lampf, Pleva, Lipkind, Prupis \& Petigrow v Gilbertson, 501 US 350, 358-62 (1991) (holding that the limitations period for Section 10(b) actions is one year from discovery of the facts constituting the alleged violation and in no event more than three years from the date of the alleged violation). The Court did not adopt the idea that the possibly longer state law fraud statutes of limitations should be applied, most of which do not constrain fraud actions with absolute periods of repose, and which instead allow statutes of limitations to run from the time of the victim's discovery of the fraud. See id at 377-78 (Kennedy dissenting).

67 See Central Bank of Denver, NA v First Interstate Bank of Denver, NA, 511 US 164, 191 (1994) (concluding that there is no aiding and abetting liability under Section 10(b)).

68 See Gustafson v Alloyd Co, Inc, 513 US 561, 584 (1995) (requiring that a plaintiff claiming a right to rescission must have been a purchaser in a public offering rather than a private placement).

69 See John W. Avery, Securities Litigation Reform: The Long and Winding Road to the Private Securities Litigation Reform Act of 1995, 51 Bus Law 335, 341-47 (1996) (collecting and discussing lower federal court opinions that dispose of private securities claims on various grounds before trial).

70 See Ramirez, 40 Wm \& Mary L Rev at 1072 (cited in note 45) ("In 1995, Congress significantly curtailed the availability of private securities claims under federal law by enacting the PSLRA."). 
system and were the primary target of the legislation.", In particular, the PSLRA limited the potential for strike suits by making it easier for courts to grant sanctions (including attorneys' fees) against plaintiffs in securities actions, ${ }^{12}$ imposing heightened pleading standards, ${ }^{73}$ staying discovery during the pendency of any motion to dismiss, limiting joint and several liability, ${ }^{75}$ prescribing strict causation standards, ${ }^{76}$ and placing limitations on securities class actions." Also, in order to promote disclosures by companies, the PSLRA instituted a safe harbor for forward-looking statements that prove false. ${ }^{78}$

71 Painter, 84 Cornell L Rev at 33-34 (cited in note 12). See also Joint Explanatory Statement of the Committee of Conference, HR Rep No 104-369, 104th Cong, 1st Sess 31 (1995), reprinted in 1995 USCCAN 730 ("The private securities litigation system is too important to the integrity of American capital markets to allow this system to be undermined by those who seek to line their own pockets by bringing abusive and meritless suits.").

72 For securities claims, courts must scrutinize pleadings to see if they comply with Rule 11 of the Federal Rules of Civil Procedure. If the court finds a violation in the complaint, the PSLRA creates a presumption that the appropriate sanction is an award of all attorneys' fees and costs incurred by the defendants in the action. See 15 USC $\$ \S 77 \mathrm{z}-1$ (c), $78 \mathrm{u}-4$ (c) (1994 \& Supp 1995). See, for example, Gurary $v$ Winehouse, 235 F3d 792 (2d Cir 2000) (finding a district court abused its discretion in not imposing sanctions mandated by the PSLRA for some of the plaintiff's claims where the claims contradicted well-settled principles of law).

73 For private securities claims under federal law, a plaintiff must plead with particularity facts "giving rise to a strong inference" of scienter. 15 USC $\$ 78 \mathrm{u}-4(\mathrm{~b})(2)$. See Ramirez, $40 \mathrm{Wm}$ \& Mary L Rev at 1074-75 (cited in note 45) (noting the difficulties in meeting this standard and the difficulties courts have had in applying this standard). Compare In re Silicon Graphics, Inc Securities Litigation, 183 F3d 970, 974 (9th Cir 1999) (finding the PSLRA raised the scienter standard to deliberate recklessness), with In re Comshare, Inc Securities Litigation, 183 F3d 542, 552-53 (6th Cir 1999) (holding that the PSLRA did not alter the prior scienter requirement of recklessness). Other circuits have agreed with the Sixth Circuit. See, for example, Greebel v FTP Software, Inc, 194 F3d 185, 201 (1st Cir 1999); Bryant v Avado Brands, Inc, 187 F3d 1271, 1285 (11th Cir 1999); In re Advanta Corp Securities Litigation, 180 F3d 525, 534-35 (3d Cir 1999); Press $v$ Chemical Investment Services Corp, 166 F3d 529, 537-38 (2d Cir 1999).

7415 USC $\$ \S 77 \mathrm{z}-1$ (b)(1), 78u-4(b)(3)(B) (1994 \& Supp 1998). See, for example, SG Cowen Securities Corp v United States District Court for the Northern District of California, 189 F3d 909, 912-13 (9th Cir 1999) (granting mandamus petition to stay discovery after successful motion to dismiss with leave to amend because of the PSLRA's stay of discovery).

75 Defendants who did not knowingly commit a violation are proportionately liable rather than jointly and severally liable. 15 USC $\$ \S 77 k(f), 78 u-4(f)(2)(A)$ (1994 \& Supp 1995). See also Painter, 84 Cornell L Rev at 33 (cited in note 12) (noting the provision is helpful for accountants and other collateral participants in securities transactions).

7615 USC $\$ 78 \mathrm{u}-4(\mathrm{~b})(4)$ ("[T]he plaintiff shall have the burden of proving the act or omission of the defendant ... caused the loss for which the plaintiff seeks to recover damages."); see also Ramirez, $40 \mathrm{Wm} \&$ Mary L Rev at 1076-77 (cited in note 45) (noting that the loss causation standard of the PSLRA overturned prior court cases requiring only but for causation or substantial factor causation).

77 The limitations include heightened court scrutiny of settlements to ensure that attorneys' fees are not excessive in proportion to the recovery, increased disclosure in any settlement, a presumption that the lead plaintiff is the largest shareholder and not the first to file suit, and limitations to ensure that the plaintiff is not a professional plaintiff. 15 USC $\$$ 77z-1(a), 78u-4(a). See, for example, California Public Employees' Retirement System v The Chubb Corp, 2001 US Dist LEXIS 142 (D NJ) (noting PSLRA requirements in denying motion for appointment of lead plaintiff).

78 The Act protects specified persons, such as issuers, underwriters, and reviewers of infor- 
The PSLRA was therefore a shift away from traditional securities statutes because the PSLRA sought to protect companies instead of shareholders. Ultimately, however, the benefits of the PSLRA do pass to shareholders because of higher corporate profits that result from not having to defend as many strike suits.

\section{B. Post-PSLRA Response by Plaintiffs' Attorneys}

Studies suggest that plaintiffs' attorneys attempted to circumvent the PSLRA's requirements by pleading their causes of action in state court. In particular, these studies note that state law class actions prior to the PSLRA rarely were filed alone in state court but were usually attached to federal claims. ${ }^{81}$ After the passage of the PSLRA, however, the studies noted an increase in the number of class actions filed solely in state court and speculated that plaintiffs were filing weaker claims in state court to avoid the more stringent federal standards. $^{82}$ The shifting to state courts was worrisome because it could effectively undermine the PSLRA's safe harbor, which would be rendered useless because it did not cover actions in state court. ${ }^{83}$ There-

mation provided by issuers, from liability (with listed exceptions) if the statement is accompanied by "meaningful cautionary statements" that identify important factors that could cause the result to differ from the statement. 15 USC $\$ \S 77 z-2,78 u-5$. Even if the forward-looking statement has no accompanying cautionary language, the plaintiff must prove that the defendant made the misstatement with actual knowledge that it was false or misleading. Id. See Harris $v$ IVAX Corp, 182 F3d 799, 804-07 (11th Cir 1999) (applying the safe harbor).

79 See B. Scott Daugherty, Comment, Unchartered Waters: Securities Class Actions in Texas After the Securities Litigation Uniform Standards Act of 1998, 31 St Mary's L J 143, 165-66 (1999) (discussing the many expenses from strike suits that corporations incur and how the PSLRA sought to stop this drain on companies' earnings, which could be better used in projects to increase profits).

80 The studies were collected and analyzed by Professor Michael A. Perino. See Perino, 50 Stan L Rev at 298-315 (cited in note 3) (noting that the PSLRA did not lead to a decline in securities class actions, but that many class actions shifted to state courts, and hypothesizing that the purpose of the shift was to avoid the PSLRA).

81 See id at 284-86 (noting that claims were rarely filed solely in state court because $10 \mathrm{~b}-5$ gave plaintiffs advantages unavailable under state law, such as the ability to plead fraud-on-themarket, and because of the difficulty in certifying a nationwide class action based on different states' standards of liability).

82 See id at 302-03, 312-13 (hypothesizing that the increase in "state only" class actions was the result of a substitution effect where plaintiffs' attorneys filed in state court when the underlying facts appeared insufficient to satisfy the PSLRA or where plaintiffs were attempting to avoid the Act's hurdles). Other commentators disputed Perino's findings, noting that the number of state court filings eventually decreased even before Congress passed the Uniform Standards Act in 1998. See Painter, 84 Cornell L Rev at 42-45 (cited in note 12) (relying on studies showing a decrease in state court securities class action filings in 1997 and speculating that the reason may have been that attorneys found state court litigation more cumbersome than expected or found the PSLRA to be less of a problem than expected).

83 See Perino, 50 Stan L Rev at 315-17 (cited in note 3) (noting that allowing suits in state court could force companies that use the safe harbor to defend suits for actions that were legal under federal law and could leave companies with a presence in multiple states exposed to multiple standards for their national actions). 
fore, the PSLRA's attempt to eliminate strike suits and afford companies greater protections failed because of the ability of plaintiffs' attorneys to file any class actions they would have filed in federal court in state court instead.

\section{The Uniform Standards Act}

1. Congressional purposes underlying the Uniform Standards Act.

In 1998, in response to the trend identified in the post-PSLRA studies, Congress passed the Uniform Standards Act. ${ }^{84}$ In particular, Congress stated its objectives in passing this legislation in its findings accompanying the Act:

[The PSLRA] sought to prevent abuses in private securities fraud lawsuits; [ ] since enactment of that legislation, considerable evidence has been presented ... that a number of securities class action lawsuits have shifted from Federal to State courts; [ ] this shift has prevented that Act from fully achieving its objectives; [ ] $\ldots$ and [ ] in order to prevent certain State private securities class action lawsuits alleging fraud from being used to frustrate the objectives of the ... [PSLRA], it is appropriate to enact national standards for securities class action lawsuits involving nationally traded securities, while preserving the appropriate enforcement powers of State securities regulators and not changing the current treatment of individual lawsuits.

Furthermore, the congressional reports noted the problems posed by class actions in state courts in general, and did not focus their analysis on those alleging fraud in connection with a purchase or a sale. In particular, the Senate Report from the Committee on Banking, Housing, and Urban Affairs noted the need for federal intervention because the state class action trend "has damaged the overall efficiency of our capital markets ... [and] has had a chilling effect on the use of the 'safe-harbor' and other important provisions of the [PSLRA]." conference committee's report noted the problems with the current system because "companies can not control where their securities are

84 Congress extensively cited Perino's findings in its reports. See Securities Litigation Uniform Standards Act of 1998, S Rep No 105-182, 105th Cong, 2d Sess 3, 3 (1998) (quoting testimony of Joseph A. Grundfest and Michael A. Perino, who reported a shift from federal to state court litigation); Securities Litigation Uniform Standards Act of 1998, HR Rep No 105-640, 105th Cong, 2d Sess 10 (1998) (quoting the report of Grundfest and Perino describing the shift); Securities Litigation Uniform Standards Act of 1998, HR Rep No 105-803, 105th Cong, 2d Sess 14 (1998) (quoting the same report).

8515 USC \& 78a note (1994 \& Supp 1998).

86 S Rep No 105-182 at 4 (cited in note 84). 
traded after an initial public offering. ... As a result, companies with publicly-traded securities can not choose to avoid jurisdictions which present unreasonable litigation costs." ${ }^{, 87}$ In order to remedy these problems, the House Committee on Commerce noted "this legislation establishes uniform national rules for securities class action litigation involving our national capital markets.... [C]lass actions relating to a 'covered security' ... alleging fraud or manipulation must be maintained pursuant to the provisions of Federal securities law, in Federal court (subject to certain exceptions)."

The report from the Senate Committee on Banking, Housing, and Urban Affairs, moreover, may indicate a congressional purpose to preempt devices, not thought of at the time of the Uniform Standards Act, which would also undermine the PSLRA. In discussing the class action definition of the Uniform Standards Act, the Committee noted,

[W]hile the Committee believes that it has effectively reached those actions that could be used to circumvent the ... [PSLRA], it remains the Committee's intent that the bill be interpreted broadly to reach mass actions and all other procedural devices that might be used to circumvent the class action definition. ${ }^{89}$

Moreover, the congressional record never mentions the existence of holding claims or the intent to have an exception for holders of stock. Therefore, the committee reports suggest a congressional purpose to create uniform national rules for class actions alleging fraud in connection with nationally traded securities and suggest that the Uniform Standards Act be construed in such a way as to ensure that its protections of the PSLRA are enforced in practice.

\section{Provisions of the Uniform Standards Act.}

While the purpose underlying the Uniform Standards Act was broad, the language of the Act limited its reach so that:

No covered class action based upon the statutory or common law of any State or subdivision thereof may be maintained in any State or Federal court by any private party alleging-

(1) an untrue statement or omission of a material fact in connection with the purchase or sale of a covered security; or

87 HR Rep No $105-803$ at 15 (cited in note 84), quoting the statement of Hon. Keith Paul Bishop, Commissioner, California Department of Corporations.

88 HR Rep No 105-640 at 9 (cited in note 84). The exceptions noted in the Committee Reports are the same ones which were incorporated into the Uniform Standards Act. See notes 9397 and accompanying text.

89 S Rep No $105-182$ at 8 (cited in note 84 ). 
(2) that the defendant used or employed any manipulative or deceptive device or contrivance in connection with the purchase or sale of a covered security.

The Act went on to state: "Any covered class action brought in any State court involving a covered security ... shall be removable to the Federal district court for the district in which the action is pending and shall be subject to [the Act's preemption]." the definition of a class action so that individual actions by more than fifty people could be consolidated and considered class actions, and when courts examine whether a common question of law or fact of such individuals predominates, courts shall disregard issues of individualized reliance on the alleged misstatement or omission. ${ }^{92}$

The Act clearly articulated certain exceptions to its broad rule that securities class actions in connection with the purchase or sale of a covered security could no longer be maintained under state law. Specifically, the Act does not apply to actions maintained in state or federal court by a private party under the law of the state of incorporation or organization, ${ }^{93}$ to derivative actions, ${ }^{94}$ to actions by state officials, ${ }^{95}$ to actions under contractual agreements between issuers and indenture trustees, ${ }^{96}$ or to the "Delaware carve-out."

$90 \quad 15$ USC $\$ 77 \mathrm{p}(\mathrm{b})$ (emphasis added). See also 15 USC $\S 78 \mathrm{bb}(\mathrm{f})(1)$ (substantially similar language in the Uniform Standards Act's amendment of the Securities Exchange Act of 1934). A "covered class action" is an action for damages sought by more than fifty persons where questions of law or fact common to those persons predominate, or an action in which a named party seeks to recover damages on behalf of herself and of those similarly situated. 15 USC $\S \S 77 \mathrm{p}(\mathrm{f})(2), 78 \mathrm{bb}(\mathrm{f})(5)(\mathrm{B})$ (1994 \& Supp 1998) (Uniform Standards Act, identically amending the Securities Act of 1933 and the Securities Exchange Act of 1934). The "in connection with the purchase or sale" language is a paraphrase of language used by Section 10(b) of the 1934 Act and 10b-5. See notes 51-52 and accompanying text. See also Abada v Charles Schwab \& Co, $68 \mathrm{~F}$ Supp 2d 1160, 1166 (S D Cal 1999) (noting that in applying the language of the Uniform Standards Act, 15 USC $\$ 78 \mathrm{bb}(\mathrm{f})(1)$, courts should consider federal cases construing the similar wording of Section 10(b) and 10b-5). A "covered security" basically means a security traded on one of the national exchanges or a security issued by an investment company. See 15 USC $\$ 77 \mathrm{r}(\mathrm{b})(1)-$ (2) (noting that a covered security is one listed on the New York Stock Exchange, the American Stock Exchange, or NASDAQ). See also 15 USC $\$ \S 77 \mathrm{p}(\mathrm{f})(3), 78 \mathrm{bb}(\mathrm{f})(5)(\mathrm{E})$ (both referring the reader to 15 USC $\S 77 \mathrm{r}(\mathrm{b})(1)-(2)$ for the definition of a covered security for purposes of preempting certain state law class actions).

$91 \quad 15$ USC $\$ \$ 77 \mathrm{p}(\mathrm{c}), 78 \mathrm{bb}(\mathrm{f})(2)$.

92 Id $\S \S 77 \mathrm{p}(\mathrm{f})(2), 78 \mathrm{bb}(\mathrm{f})(5)(\mathrm{B})$. By having courts avoid looking into individualized instances of reliance, the Act allows for class action treatment even where a state may not have allowed class action treatment because of the issues of individualized reliance. See notes 19-22 and accompanying text.

93 See 15 USC $\$ \$ 77 p(d)(1)(A), 78 b b(f)(3)(A)(i)$.

94 See id $\$ \S 77 \mathrm{p}(\mathrm{f})(2)(\mathrm{B}), 78 \mathrm{bb}(\mathrm{f})(5)(\mathrm{C})$.

95 See id $\$ \$ 77 \mathrm{p}(\mathrm{d})(2), 78 \mathrm{bb}(\mathrm{f})(3)(\mathrm{B})$.

96 See id $\$ \$ 77 \mathrm{p}(\mathrm{d})(3), 78 \mathrm{bb}(\mathrm{f})(3)(\mathrm{C})$.

97 The "Delaware carve-out" includes the following two exceptions, which can still be brought as class actions in state court: Class actions involving "the purchase or sale of securities by the issuer or an affiliate of the issuer exclusively from or to holders of equity securities of the 
ever, limited the possible adverse effects of these exceptions by allowing a federal court to order a stay of discovery in "any private action in a State court" while a federal action is pending. ${ }^{98}$ In this way, the Act sought to ensure that plaintiffs' attorneys could not file parallel actions in state and federal court and then use the state court discovery process to force a settlement of the claims.

While the Uniform Standards Act included exceptions to allow certain class actions in state court, the clear intent of the statute was to close the loopholes in the PSLRA, which had allowed plaintiffs' attorneys to avoid the Act's requirements by filing cases in state courts. In this way, Congress sought to ensure that the protections of the PSLRA would be afforded to all companies facing securities class actions, besides the listed exceptions.

\section{The Revival of Holding Claims}

In the aftermath of the Uniform Standards Act, plaintiffs' attorneys have revived common law holding claims and have been filing such claims in state courts as class actions. ${ }^{100}$ The federal district courts that have dealt with holding claims removed from state court under the Uniform Standards Act have held that such actions must be remanded back to state court because holding claims do not come within the literal wording of the Act because they do not allege fraud in connection with the "purchase or sale of a covered security."

issuer; or [ ] any recommendation, position, or other communication with respect to the sale of securities of the issuer that [] is made by or on behalf of the issuer or an affiliate of the issuer to holders of equity securities of the issuer; and [ ] concerns decisions of those equity holders with respect to voting their securities, acting in response to a tender or exchange offer, or exercising dissenters' or appraisal rights." See id $\$ \$ 77 \mathrm{p}(\mathrm{d})(1)(\mathrm{B}), 78 \mathrm{bb}(\mathrm{f})(3)(\mathrm{A})(\mathrm{ii})$.

98 Id $\$ \S 77 z-1(b)(4), 78 u-4(b)(3)(D)$. The House Report noted that the Committee on Commerce intended "that courts use this provision liberally, so that the preservation of State court jurisdiction of limited individual securities fraud claims does not become a loophole through which the trial bar can engage in discovery not subject to the stay of the [PSLRA]." HR Rep No 105-640 at 18 (cited in note 84).

99 See Part II.B.

100 See, for example, Gordon v Buntrock, 2000 US Dist LEXIS 5977, *2-4 (N D Ill) (holding claim class action alleging negligent misrepresentation, common law fraud, breach of fiduciary duty, and aiding and abetting breach of fiduciary duty); Greenfield v Fritz Companies, Inc, 82 Cal App 4th 741, 98 Cal Rptr 2d 530, 533 (Cal App 2000), review granted, 101 Cal Rptr 2d 653, 12 P3d 1068 (Cal 2000) (holding claim class action alleging fraud and negligent misrepresentation); Lalondriz v USA Networks, Inc, 54 F Supp 2d 352, 353 (S D NY 1999) (holding claim class action under Delaware law based on a theory of breach of fiduciary duty of disclosure), affd on reconsideration, 68 F Supp 2d 285 (S D NY 1999).

101 See, for example, Gordon, 2000 US Dist LEXIS 5977 at *9-14 (remanding because the plaintiff expressly limited his claim to damages for holding the stock, which is not in connection with the purchase or sale of a covered security); Lalondriz, 68 F Supp $2 \mathrm{~d}$ at 286 (remanding because the holding claim was not covered by the "in connection with the purchase or sale" language of the Uniform Standards Act). These decisions are consistent with treating the "in connection with a purchase or sale" language of the Uniform Standards Act in the same manner 
Since the passage of the Uniform Standards Act, some courts and commentators have interpreted the Delaware Supreme Court case Malone $v$ Brincat ${ }^{102}$ as endorsing holding claims as direct actions for a breach of the fiduciary duty of disclosure, ${ }^{103}$ and the California Supreme Court has agreed to review an appellate court decision that allowed a holding claim class action. ${ }^{104}$ If Delaware, California, or any other state definitively acknowledges common law holding class actions, a large percentage of companies could be subject to such claims. ${ }^{105}$ Consequently, despite Congress's attempt to limit strike suits through the passage of the PSLRA and the Uniform Standards Act, the revival of state law holding claims may defeat Congress's purpose by allowing a state forum for conducting class action strike suits.

\section{IMPLIED PREEMPTION OF HOLDING ClAIM CLASS ACTIONS}

This Part examines the doctrine of implicit preemption of state laws that obstruct the purpose of a federal statute. It then argues that the implicit preemption doctrine should be applied to conclude that

courts have treated Section 10(b) of the 1934 Act and 10b-5 because Blue Chip Stamps, 421 US 723 , held that the phrase "in connection with a purchase or sale" does not include the failure to sell. See id at 727,749 (declining to abandon the strict purchaser-seller requirement). See also Abada v Charles Schwab \& Co, 68 F Supp 2d 1160, 1166 (S D Cal 1999) (noting that in applying the language of the Uniform Standards Act, courts should consider federal cases construing Section 10(b) and 10b-5). Also, remand in these cases is consistent with the treatment of removal statutes in general because courts strictly construe such statutes, with doubts as to removability usually resolved in favor of remanding cases to state court. See Shamrock Oil \& Gas Corp v Sheets, 313 US 100, 108-09 (1941) (strictly construing a removal statute); Doe v Allied-Signal, Inc, 985 F2d 908, 911 (7th Cir 1993) (federal courts resolve doubt in removal statutes in favor of remand).

102722 A2d 5, 14 (Del 1998) (allowing holders of stock who claimed a breach of fiduciary duty of disclosure to replead a direct cause of action or a derivative claim).

103 See Gordon, 2000 US Dist LEXIS 5977 at *9 (characterizing Malone as ruling that "holders of stock in Delaware corporations ... may state valid claims under state common law theories of breach of fiduciary duty for nondisclosure against directors, officers, and auditors without running afoul of federal securities laws"); Derdiger v Tallman, 2000 Del Ch LEXIS 107, *23-24 (distinguishing Malone because the plaintiffs Derdiger wishes to represent are not mere holders of the stock as in Malone); Kim, Note, 74 Wash L Rev at 1172-73 (cited in note 35) (noting that Malone allowed holders to bring a direct claim for damages).

104 See Greenfield, 98 Cal Rptr 2d 530.

105 Even if Delaware has accepted holding claims, if Delaware courts continue to deny class certification for common law fraud class actions, it is unlikely that Delaware courts would allow a common law holding class action. See notes 19-20 and accompanying text. But see Gordon, 2000 US Dist LEXIS 5977 at *2-4, and Lalondriz, 54 F Supp 2d 352, both of which were holding claim class actions brought under Delaware law, in non-Delaware courts. Even if a single state allows holding claims as class actions, a likely outcome because most courts allow class actions even when individual reliance must be proved, see note 22 , many public companies would have holders in all fifty states who could possibly file suit. Of course, in such situations, the plaintiff would need to obtain personal jurisdiction over the defendant-corporation, but if the corporation does significant business in the state, it is likely that the plaintiff will have jurisdiction over the defendant. For a general discussion, see Uniform Interstate and International Procedure Act $\S 1.03$, in 13 ULA 357, 361 (West 1986). 
holding claim class actions obstruct the purpose of the Uniform Standards Act and are therefore implicitly preempted by the Act. This Part also examines the deterrent and compensatory effect of concluding that holding claim class actions are implicitly preempted.

\section{A. Preemption}

\section{General preemption doctrine.}

Federal law supersedes state law under the Supremacy Clause of the Constitution, ${ }^{106}$ and accordingly, Congress has the power to preempt state actions. ${ }^{10}$ Congress can exercise this power in a number of ways. ${ }^{108}$ First, it may explicitly preempt a state law or cause of action. For example, the Uniform Standards Act expressly preempts class actions alleging fraud in connection with the purchase or sale of a covered security when the class action is based on state law (with the already noted exceptions). ${ }^{109}$ Second, courts may find that a regulatory scheme occupies an entire field of law, such as federal regulation of oil tankers, thereby precluding any state role in that subject. ${ }^{110}$ Finally, state laws are preempted to the extent they conflict with federal statutes." This form of preemption occurs in two situations: when it is impossible for a party to comply with both state and federal law, ${ }^{112}$ and where the state law or cause of action "stands as an obstacle to the accomplishment and execution of the full purposes and objectives of Congress.",113

\section{Obstacle preemption.}

As with any other form of preemption, obstacle preemption ${ }^{114}$ can be used to preempt a state statute ${ }^{115}$ or a state common law cause of

106 US Const Art VI, cl 2.

107 See Crosby v National Foreign Trade Council, 120 S Ct 2288, 2293 (2000) (stating that congressional power to preempt state law is a fundamental principle of the Constitution).

108 See id at 2293-94 (noting the current test for preemption).

10915 USC $\$ \S 77 p(b), 78 b b(f)(1)$. See also Part II.C.2. For the exceptions, see notes 93-97 and accompanying text.

110 See, for example, United States v Locke, 529 US 89, 115-16 (2000) (finding state regulation of oil tankers preempted because Congress has occupied this field).

111 See, for example, Crosby, $120 \mathrm{~S} \mathrm{Ct}$ at 2302 (finding conflict preemption of a Massachusetts law that conflicted with a federal act delegating discretion to the President in deciding sanctions against Burma).

112 See, for example, Florida Lime \& Avocado Growers, Inc v Paul, 373 US 132, 142-43 (1963) (stating in dicta that when compliance with both state and federal law is impossible the obstacle preemption doctrine's impossibility prong will apply). Note, however, that the Court has rarely used this prong. See Caleb Nelson, Preemption, 86 Va L Rev 225, 228 (2000) (noting that the physical impossibility prong is "vanishingly narrow").

113 Crosby, $120 \mathrm{~S} \mathrm{Ct}$ at 2294, quoting Hines v Davidowitz, 312 US 52, 67 (1941).

114 There is scholarly debate about whether obstacle preemption is a constitutional doctrine or a statutory doctrine that reads an implied clause into every federal statute forbidding states to 
action $^{116}$ that undermines the purpose of the federal law. For instance, in Geier $v$ American Honda Motor Co, ${ }^{117}$ the Supreme Court found a common law tort action preempted because the state tort action would obstruct the federal purpose of gradually developing a mix of alternative restraint devices for safety-related reasons through a uniform national standard. ${ }^{118}$ Similarly, in International Paper Co $v$ Ouellette, ${ }^{119}$ the Supreme Court found a common law nuisance suit preempted, noting that "it is not enough to say that the ultimate goal of both federal and state law is to eliminate water pollution. A state law also is pre-empted if it interferes with the methods by which the federal statute was designed to reach this goal." ${ }^{120}$ The International Paper Court then found obstacle preemption because the federal amendments in question had as their purpose the creation of "clear and identifiable' discharge standards," and allowance of the state lawsuit "would undermine the important goals of efficiency and predictability in the permit system."

When examining whether a state action stands as an obstacle to Congress's objectives, the Supreme Court recently noted in Crosby $v$ National Foreign Trade Council" that "[w] hat is a sufficient obstacle is a matter of judgment, to be informed by examining the federal statute as a whole and identifying its purpose and intended effects." ${ }^{123}$ In so doing, the Crosby Court not only examined the statute's text to find the congressional purpose and objectives, but also extensively examined the federal act's legislative history, including congressional re-

enact or enforce laws that would obstruct Congress's purposes and objectives. See Nelson, $86 \mathrm{Va}$ L Rev at 266-78 (cited in note 112) (describing arguments regarding what type of doctrine obstacle preemption is and proposing that neither view of the doctrine is correct).

115 See, for example, Crosby v National Foreign Trade Council, 120 S Ct 2288, 2294, 2302 (2000) (holding preempted a Massachusetts law barring state entities from buying goods from companies doing business with Burma after Congress had imposed its own sanctions).

116 See Geier v American Honda Motor Co, 120 S Ct 1913, 1919-28 (2000) (holding that a common law cause of action would obstruct the purpose of Federal Motor Vehicle Safety Standard 208); International Paper Co v Ouellette, 479 US 481, 497 (1987) ("It would be extraordinary for Congress, after devising an elaborate permit system that sets clear standards, to tolerate common-law suits that have the potential to undermine this regulatory structure."). But see Susan Raeker-Jordan, The Pre-Emption Presumption that Never Was: Pre-Emption Doctrine Swallows the Rule, 40 Ariz L Rev 1379, 1468-69 (1998) (arguing that courts should imply a strict presumption against preemption for common law claims).

$117120 \mathrm{~S} \mathrm{Ct} 1913$ (2000).

118 Id at 1928.

119479 US 481 (1987).

120 Id at 494.

121 Id at 496, quoting Federal Water Pollution Control Act Amendments of 1971, S Rep No 92-414, 92d Cong, 1st Sess 81 (1971).

$122120 \mathrm{~S} \mathrm{Ct} 2288$ (2000).

123 Id at 2294. 
ports, to support its conclusion that Massachusetts's law on sanctions against Burma obstructed the purpose of the federal statute. ${ }^{124}$

While there is a presumption that state law should not be preempted, especially in areas where states have long had a significant role, this presumption is overcome where the state act stands as an obstacle to the objectives of Congress. ${ }^{125}$ Additionally, the Geier Court found that the existence in the federal statute of both express preemption of other state actions and a saving clause specifically exempting other actions does not alter the test for obstacle preemption. ${ }^{126}$

\section{Obstacle preemption in corporate and securities law.}

Three groups of recent cases have raised issues of obstacle preemption in corporate and securities law. Specifically, the highest courts of New York, ${ }^{127}$ Minnesota, ${ }^{128}$ and Illinois, ${ }^{129}$ as well as other states' intermediate appellate courts, ${ }^{130}$ have found obstacle preemption of state

124 Id at 2295 n 9, 2296 nn 11-12, 2297 n 13, 2298 n 15, 2299 n 17, 2301 n 23 (finding support in its conclusion that the state action in question would obstruct Congress's purpose and objectives by extensively examining the congressional record). The Supreme Court has examined the congressional history in preemption cases on other occasions as an aid to finding the congressional purpose and objectives. See, for example, International Paper, 479 US at 493-97 (examining the congressional reports in finding that the purpose and history of the federal act supported preemption of a common law cause of action); Rice v Sante Fe Elevator Corp, 331 US 218, 233-34 (1947) (looking to committee reports in finding the congressional purpose).

125 See Rice, 331 US at 230 (noting that there is an "assumption that the historic police powers of the States were not to be superseded by the Federal Act unless that was the clear and manifest purpose of Congress," but finding preemption despite the presumption); Nelson, $86 \mathrm{Va}$ L Rev at 288-89 (cited in note 112) (noting that while the Supreme Court has stressed a presumption against preemption, its preemption decisions have been erratic).

126 Geier, $120 \mathrm{~S} \mathrm{Ct}$ at 1919-22 (noting the reasons for not implying a special burden in such situations even where the saving clause said that "compliance" with the federal safety standard did not exempt a party from liability under state law), quoting 15 USC $\$ 1397(\mathrm{k})$ (1988). In noting that there is no special burden, Geier clarified an earlier unclear statement on the issue of a special burden in the presence of an express preemption statement in Freightliner Corp $v$ Myrick, 514 US 280, 288-89 (1995) (suggesting such a burden when it overturned the implication in Cipollone v Liggett Group, Inc, 505 US 504, 517 (1992), that the existence of express preemption in the statute does not allow a court to also apply obstacle preemption to the statute).

127 Guice v Charles Schwab \& Co, Inc, 651 NYS2d 352, 674 NE2d 282, 288-91 (1996) (holding that federal regulation of disclosure of order flow payments preempted state civil actions based on common law principles). But see Anthony E. Szydlowski, Comment, Preemption in the Securities Industry: A Diminished Standard?, 74 St John's L Rev 259 (2000) (arguing that the Guice court was wrong to find obstacle preemption).

128 Dahl v Charles Schwab \& Co, Inc, 545 NW2d 918, 924-26 (Minn 1996) (finding that federal law implicitly preempts common law and state statutory causes of action for acceptance of order flow payments).

129 Orman v Charles Schwab \& Co, Inc, 179 Ill 2d 282, 688 NE2d 620, 626 (1997) (finding that federal law preempted claims under state common law for the receipt of order flow payments).

130 McKey v Charles Schwab \& Co, Inc, 79 Cal Rptr 2d 213,219 (Cal Ct App 1998) (following Guice and finding implied preemption of common law claim); Shulick v PaineWebber, Inc, 700 A2d 534, 538 (Pa Super Ct 1997) (adopting the reasoning in Guice), affd 722 A2d 148 (Pa 1998); Eirman v Olde Discount Corp, 697 S2d 865, 866 (Fla Ct App 1997) (adopting the reason- 
common law actions regarding the receipt of order flow payments by reasoning that such actions obstruct the purpose of Congress's 1975 amendments to the 1934 Act and SEC Rule 10b-10. For example, in Guice v Charles Schwab \& Co, Inc, ${ }^{131}$ the New York Court of Appeals, after examining the congressional history of the federal amendments, noted that:

Permitting the courts of each State to impose civil liability ... for failure to meet more stringent common-law agency standards of disclosure of receipt of order flow payments (rather than the Federally mandated uniform [rules]) would inevitably defeat the congressional purpose of enabling the SEC to develop and police that "coherent regulatory structure" for a national market system. Securities broker-dealers, confronted with the risk of nationwide class action civil damage liability including ... punitive damages ... would be impelled to tailor their disclosures to each State's [common law] ... , and ... the SEC disclosure requirements would have little, if any, influence....

[In such a situation,] many brokerage firms [may] abandon[ ] ... order flow payments altogether, [a] ... drastic undermining of congressional objectives.

On the other hand, in CTS Corp v Dynamics Corp of America, ${ }^{133}$ the United States Supreme Court did not find obstacle preemption where an Indiana statute could lead to delays in tender offers even though the process of tender offers was regulated by the federal Williams Act, whose purpose may have been ensuring a balance between the interests of corporate managers who oppose tender offers and of offerors. ${ }^{134}$ Unlike a prior Supreme Court case, Edgar v MITE Corp, ${ }^{135}$ which struck down an Illinois statute that could have delayed tender offers indefinitely and thus undermine the federal balance, ${ }^{136}$ the statute in CTS did not unreasonably delay tender offers, and thus the Court held it did not obstruct the purpose and objectives of the Williams Act. ${ }^{137}$ In so noting, the Court in CTS stated that it would not quickly find obstacle preemption because of the long-standing prevalence of state regulation of the area. ${ }^{138}$ Finally, in Diamond Multimedia

ing of Guice, Orman, and Dahl). But see Dumont v Charles Schwab \& Co, Inc, 717 S2d 1182, 1184-87 (La Ct App 1998) (rejecting obstacle preemption, but finding express preemption).

131651 NYS2d 352, 674 NE2d 282 (1996).

132 Id at $290-91$.

133481 US 69 (1987).

134 Id at 79-81.

135457 US 624 (1982) (plurality opinion).

136 Id at 637.

$137 C T S, 481$ US at 85 (stating that a fifty day delay at most is not an unreasonable delay).

138 Id at 86-87. See also Amanda Acquisition Corp v Universal Foods Corp, 877 F2d 496, 
Systems, Inc v Superior Court of Santa Clara County, ${ }^{139}$ the California Supreme Court refused to find a state court class action, by purchasers of stock filed before the Uniform Standards Act, implicitly preempted by the PSLRA or the Uniform Standards Act. ${ }^{100}$ Noting that the Uniform Standards Act itself states it would not apply "to any action commenced before and pending on the date of the enactment of th[e] Act, ${ }^{, 141}$ the court held that allowing the class action did not obstruct the purpose or objective of any federal law.

\section{B. Preemption of Holding Claim Class Actions}

\section{Holding claims obstruct the purpose of the Uniform Standards Act.}

No federal statute expressly preempts holding claim class actions nor has Congress occupied the field of securities law. ${ }^{1.3}$ Moreover, the impossibility prong of conflict preemption is inapplicable $-\mathrm{a}$ holding claim class action is technically consistent with federal securities law, since federal law requires fraud in connection with the purchase or sale of a security. Holding claim class actions, however, stand as an obstacle to the accomplishment and execution of the purposes and objectives of Congress in passing the Uniform Standards Act and thus raise the issue of obstacle preemption. In accordance with Geier, ${ }^{\text {1,4 }}$ the Uniform Standards Act's express preemption provisions and savings clause $^{\text {1us }}$ do not affect the obstacle preemption analysis.

502 (7th Cir 1989) (finding that a state law making tender offers less attractive was not preempted by the Williams Act and noting the presumption against preemption applies because states have regulated corporate affairs since before the beginning of the nation).

13919 Cal 4th 1036, 968 P2d 539 (1999).

140 In dicta, the court noted:

By enacting only a class action limitation, when [Congress] could have barred all actions based on state law to recover losses caused by market manipulation, Congress has confirmed the independent force of state securities law. Had Congress believed that its goals could not be accomplished if suits based on state law were permitted ... all actions based on state law, not simply class actions, would have been banned.

Id at 545 n 12 . The dicta, however, do not address a situation like holding claim class actions, which actually obstruct the Uniform Standards Act because it is unlikely that Congress would want to uphold a class action that undermined the Act. See Part III.B.1.

14115 USC $\$ 77 \mathrm{p}$ note.

142 Diamond Multimedia, $968 \mathrm{P} 2 \mathrm{~d}$ at $545 \mathrm{n} 12$.

143 Note that Congress explicitly included in the Uniform Standards Act exceptions allowing states authority in securities laws, including the ability to bring enforcement actions under state law. See note 95 and accompanying text.

144 See Geier, $120 \mathrm{~S} \mathrm{Ct}$ at 1918-19 (finding obstacle preemption even where a federal act included a saving clause, which noted that "[c]ompliance with" the federal standard "does not exempt any person from any liability under common law"), quoting 15 USC $\$ 1397$ (k) (1998).

145 See Uniform Standards Act $\S 101$ (a), codified at 15 USC $\$ 77 \mathrm{p}(\mathrm{a})$. This saving clause also amends the 1934 Act's saving clause, which read "the rights and remedies provided by this title shall be in addition to any and all other rights and remedies that may exist at law or in equity," 
In order to find obstacle preemption, courts first must examine the Uniform Standards Act as a whole and identify its purpose and intended effects. The very name of the Act, "The Securities Litigation Uniform Standards Act," and the congressional findings accompanying the $\mathrm{Act}^{147}$ demonstrate Congress's intent to create uniform national standards for securities litigation. In particular, the findings note the intent to prevent state actions from being used to frustrate the objectives of the PSLRA. ${ }^{148}$ Allowing holding claim class actions for holding stock, which would be a "covered security" under the Uniform Standards Act, ${ }^{199}$ however, could undermine congressional intent because each dramatic drop in stock price will cause stockholders to regret that they continued to hold their stock. Such stockholders likely will claim that they would have sold their stock before the price drop if the corporation had informed them of the problem causing the drop and that the corporation fraudulently induced them to hold their stock.

Thus, almost any securities fraud class action that could be brought in federal court could instead be filed in state court under state law as a holding claim. ${ }^{150}$ Such a situation would undermine the effect of the Uniform Standards Act as a protection of the PSLRA's heightened standards against strike suits, and may lead companies not to use the PSLRA's safe harbor out of fear of potential liability in a class action under state law. These were the exact worries that led to the initial passage of the Uniform Standards Act. ${ }^{151}$ Moreover, the Uniform Standards Act was structured specifically to preempt state causes of action in class action form. ${ }^{152}$ Consequently, finding preemption of state holding claim class actions would hardly be an intrusion on Congress's lawmaking prerogative, and instead is consistent with the structure and purpose of the Act, which preempts state class actions in order to create uniform national standards.

Additionally, following Crosby, in identifying a statute's purposes and intended effects it is helpful to examine an act's legislative history. ${ }^{153}$ Such an examination fortifies the contention that holding claim class actions would obstruct the congressional purpose and intended

by adding the exceptions of the Uniform Standards Act. See 15 USC $\S 78 \mathrm{bb}$ (a).

146 See notes 114-42 and accompanying text.

147 See Part II.C.1.

148 See 15 USC $\$ 78$ a note.

149 See note 90 for the definition of a covered security.

150 This is especially worrisome because holding claims can rarely be disposed of prior to trial and force settlements of even the most nonmeritorious claims. See Blue Chip Stamps, 421 US at 742 (noting that such claims are ideal strike suits).

151 See Parts II.A-B for a discussion of the purposes of the PSLRA and plaintiffs' attorneys' reaction to the PSLRA, which prompted the passage of the Uniform Standards Act.

152 See Part II.C.2.

153 See note 124 and accompanying text. 
effect in passing the Act. In particular, the Act's legislative history focused on the need for uniformity of all securities fraud class actions (besides the expressed exceptions) in order to thwart plaintiffs' attorneys' abilities to migrate to state court and thereby circumvent the PSLRA and did not evince an obsession with the purchase or sale requirement of the Act. Also, holding claim class actions are like the procedural devices that the Committee on Banking, Housing, and Urban Affairs ${ }^{154}$ worried could undermine the Act's class action definition because holding claim class actions could circumvent the very need for the Act and its class action definition by allowing class actions in state court possibly whenever there is a drop in the price of stock. Finally, the fact that holding claims were never even mentioned in the committee reports $^{155}$ should not lead to the implication that Congress intended to allow such claims, but instead show that Congress may not have been aware that certain states recognize holding claims and therefore may not have realized that plaintiffs could bring securities class actions as holding claims. ${ }^{156}$ Therefore, obstacle preemption is consistent with the congressional purpose in passing the Uniform Standards Act.

The fact that the structure of the statute and the legislative history support obstacle preemption makes holding claim class actions more like Guice, Geier, and International Paper, than Diamond Multimedia or CTS. For instance, as in Geier, where allowing a common law action would obstruct the federal purpose of creating uniform national safety standards, ${ }^{157}$ allowing holding claims would obstruct the federal purpose of creating a uniform national federal standard for se-

154 See note 89 and accompanying text.

155 While the legislative history does mention a congressional intent not to preempt corporate fiduciary breach of disclosure claims for certain types of actions, the actions mentioned in the legislative history are exactly those that were included in the Delaware carve-out. See, for example, S Rep No 105-182 at 6 (cited in note 84). Importantly, at the time Congress recognized the importance of the breach of fiduciary duty of disclosure claims, courts had limited this duty to occasions when the corporation seeks specific shareholder action. See Loudon $v$ ArcherDaniels-Midland Co, 700 A2d 135, 137-38 (Del 1997) (stating that fiduciary duty of disclosure only applies when the corporation is seeking stockholder action). Therefore, the fact that Congress intended to exclude certain specified claims regarding the breach of the fiduciary duty of disclosure should not be implied to mean that Congress would want to exclude breach of fiduciary duty claims under Malone's subsequent changes, which now allow a direct claim whether or not the corporation is seeking shareholder action, and which now may allow holding claims whenever stockholders claim an officer or manager knowingly disseminated false information that caused a drop in the stock price. See notes 34-36 and accompanying text. Such claims often could be brought as state court class action strike suits, and therefore Malone holding claim class actions are a loophole in the Uniform Standards Act and obstruct its purpose.

156 The implication that Congress may not have even known about holding claims is consistent with the fact that very few such claims had been brought prior to 1998 . See notes 24-28 and accompanying text for a discussion of each of the known holding claims prior to 1998.

157 See note 117 and accompanying text. 
curities class actions because plaintiffs could continue to file strike suits as class actions in state court. Moreover, like International Paper, it is not enough to say that the ultimate goal of holding claim class actions and federal class actions is to eliminate securities fraud because the existence of holding claim class actions could undermine the important goals of efficiency in saving companies from being forced to defend strike suits, and predictability for companies who want to utilize the safe harbor. ${ }^{158}$ Finally, like in Guice, where state common law actions could effectively eliminate order flow payments, which the federal government sought to promote, ${ }^{159}$ allowing holding claim class actions may force companies not to use the PSLRA's safe harbor out of fear of state law liability, even after Congress specifically amended the federal securities laws so that state law class actions would not undermine the PSLRA.

Holding claims' obstruction of the purpose of the Uniform Standards Act was not present, however, in Diamond Multimedia, because in that case, Congress had expressly decided that the Act should not preempt pending actions. ${ }^{160}$ Moreover, allowing pending class actions to proceed after the Act does not present the problem of class actions as strike suits nor chill use of the safe harbor on a going forward basis because the only class actions exempted by Diamond Multimedia are those that are already known on the date of the Act. Also, unlike CTS, where the state law in question did not impose an unreasonable bur$\operatorname{den}^{161}$ on the federal purpose of balancing competing interests regarding tender offers, holding claim class actions may impose a significant burden on the federal purposes of protecting companies from strike suits and of promoting forward-looking statements. Additionally, even though states have long dealt with securities regulation through common law actions as in Guice, Geier, and International Paper, holding claim class actions obstruct the federal Act's purpose and objectives and should be able to overcome the presumption against preemption.

Finally, courts should not wait to see how holding claim class actions develop over time. Preemption is needed whenever such claims arise because the existence of holding claim class actions by itself may deter corporations from using the safe harbor. In Guice, the New York Court of Appeals recognized that the mere existence of a state cause of action could interfere with a federal scheme. ${ }^{162}$ Furthermore, focusing on companies' perceptions instead of waiting to see how state law claims develop is consistent with the history of the Uniform Standards

\footnotetext{
158 See note 119-21 and accompanying text for a discussion of International Paper.

159 See notes $127-32$ and accompanying text.

$160968 \mathrm{P} 2 \mathrm{~d}$ at $545 \mathrm{n} 12$. See also notes $139-42$ and accompanying text.

161 See note 137 and accompanying text.

162 See notes 132 and accompanying text.
} 
Act itself, which preempted state class actions because of the rise in such actions in 1996, the year after the PSLRA was enacted, even though in 1997 studies showed a drop in the number of class actions compared to pre-PSLRA levels. ${ }^{163}$ Even with this information, Congress passed the Uniform Standards Act preempting state securities class actions to assure companies that they could use the safe harbor without worry of strike suits based on state law in the future. Therefore, in accordance with the purposes and objectives of Congress, courts should preempt holding claim class actions when the stock held would be a "covered security" under the Uniform Standards Act.

\section{Deterrent effect of preemption.}

There is little reason to fear that preempting holding claim class actions will lead to inadequate deterrence. Congress does not need holding claims to deter corporate wrongdoing because if there really was a misrepresentation by a company, surely some class of plaintiffs could maintain a class action in federal court. In particular, if a company, through a misrepresentation, induces people to hold their stock, the damage that the holders are claiming flows from a change in the stock price. ${ }^{165}$ In order for there to be a change in the stock price of a publicly traded company, someone must buy and someone else must sell the stock. Under the doctrine of "fraud-on-the-market," the purchasers and sellers of the security could sue in federal court (in class action form if appropriate) through a $10 \mathrm{~b}-5$ action merely by showing that the misrepresentation affected the stock price. ${ }^{166}$ In addition, those who could bring a holding claim class action or other shareholders may also be able to bring a derivative claim, if they can meet the procedural prerequisites, ${ }^{167}$ for the loss in value of their stock resulting from officers' or directors' wrongdoing. ${ }^{168}$ Moreover, in states that rec-

163 See, for example, HR Rep No 105-640 at 47-49 (cited in note 84) (noting that in 1997 only forty-four state securities law class actions were filed, which is lower than in 1994 and 1996); S Rep No 105-182 at 12-14 (cited in note 84) (noting that despite the drop in filings in state courts, supporters of preemption still argue that the "mere threat of state litigation is a problem").

164 This Comment does not propose that federal courts faced with removed holding claim class actions should find preemption. See note 101. Even where a federal court remands a removed holding case, remand does not preclude the state court's subsequent addressing of the preemption issue in the remanded case. See In re Loudermilch, 158 F3d 1143, 1146 (11th Cir 1998) (stating that district court's decision to remand does not have preclusive effect on state court's resolution of preemption defenses).

165 See Part I.A.1.

166 See note 18.

167 See note 31 for a list of the procedural prerequisites for a derivative suit.

168 See Part I.A.2, noting that holders may also bring derivative claims, and text accompanying note 94, noting that the Uniform Standards Act explicitly exempts derivative actions from preemption. Importantly, in light of Malone, $723 \mathrm{~A} 2 \mathrm{~d}$ at 14, a shareholder of a Delaware corpora- 
ognize holding claims, the holder of stock may bring an individual claim. Furthermore, the SEC may be able to bring an enforcement action against a person who violates an SEC rule or regulation (such as 10b-5), which may subject such person to civil penalties, ${ }^{169}$ there may be criminal penalties for making such statements, ${ }^{170}$ and states may bring enforcement actions against violators of blue sky laws. ${ }^{171}$ Therefore, holding claim class actions are not necessary to deter companies from making misrepresentations because they would otherwise be deterred by other suits.

Furthermore, holding claims need to be preempted in order to deter wrongdoing by plaintiffs' attorneys. The PSLRA includes monetary sanctions for wrongful attorney behavior in bringing strike suits, ${ }^{12}$ but if plaintiffs' attorneys can avoid these sanctions by filing in state courts, which may not have such sanctions, the potential deterrence against strike suits will be less effective. Plaintiffs' attorneys can bring strike suits in the form of state holding claim class actions in states that recognize holding claims, ${ }^{173}$ and without preemption, attorneys may not be otherwise deterred by sanctions from bringing strike suits. Therefore, in order effectively to deter strike suits, which was Congress's purpose under the PSLRA and the Uniform Standards Act, courts should interpret holding claim class actions as implicitly preempted.

\section{Compensation of injured parties in light of preemption.}

Preemption of holding claim class actions may leave injured parties with other remedies, which may compensate injured parties more in accordance with congressional purposes than allowing the holding claim class actions. Holders of stock may be able to bring their claims as derivative actions, ${ }^{174}$ which can indirectly compensate shareholders

tion may be able to bring a derivative suit whenever an officer or director knowingly disseminates false information. See notes 34-36 and accompanying text.

169 See 15 USC $\$ \$ 77 \mathrm{t}(\mathrm{d})(1), 78 \mathrm{u}(\mathrm{d})(3)(\mathrm{A}), 80 \mathrm{a}-12(\mathrm{e})(1), 80 \mathrm{~b}-9(\mathrm{e})(1)$. See, for example, SEC $v$ Interlink Data Network of Los Angeles, Inc, Fed Secur L Rptr (CCH) II 98,049 at 98,476 (C D CA 1993) (approving SEC penalty of twelve million dollars for securities law violations).

170 See, for example, United States v Zolp, 659 F Supp 692 (D NJ 1987), affd as United States $v$ Livieratos, 853 F2d 922 (3d Cir 1988) (unpublished opinion) (a criminal case for securities fraud).

171 State enforcement actions are specifically exempted by the Uniform Standards Act. See note 95 and accompanying text.

172 See Part II.A.

173 For a discussion of why holding claims can almost always be brought whenever there is a drop in price, see Part III.B.1.

174 See Part I.A.2. See also Blue Chip Stamps, 421 US at 738 (noting that holders of stock can likely bring derivative claims). Moreover, the holder would be compensated equally if any other shareholder brought an effective derivative action because the recovery goes to the corporation and compensates all shareholders through an increased value of their stock. For a general 
by increasing the price of their stock, ${ }^{175}$ or as individual claims ${ }^{176}$ in states that allow holding claims, ${ }^{17}$ because the Uniform Standards Act expressly preserves derivative and individual claims. ${ }^{178}$ While preemption of holding claim class actions may leave an injured party with less compensation, Congress's passage of the PSLRA and the Uniform Standards Act shows that Congress is willing to sacrifice some methods of compensation in the interest of curbing strike suits. Derivative suits $^{179}$ and individual holding claims ${ }^{180}$ may be able to compensate in-

discussion, see Klein and Coffee, Business Organization and Finance at 196 (cited in note 31) (noting the theoretical flow of a recovery in a derivative suit). It is likely that if there was a breach of duty by a manager or a director, a plaintiffs' attorney will have a strong incentive to bring the case. See id (noting that the corporation pays plaintiffs' attorneys directly for bringing successful derivative actions). While the named plaintiff shareholder does not usually get a monetary award apart from the gain through the corporation for a successful suit, under certain circumstances, such awards are granted. See, for example, Lynch v Patterson, 701 P2d 1126, 1136 (Wyo 1985) (allowing payment to plaintiff in percentage of his stock ownership where a corporate recovery would return the funds to the hands of the wrongdoers).

175 See note 32.

176 Individual holding claims should not be held to be implicitly preempted because the legislative history reflects Congress's worries about class actions only, and Congress explicitly excluded individual claims. See Part II.C. Moreover, there is evidence that individuals regularly bring private securities actions. See Charles M. Yablon, A Dangerous Supplement? Longshot Claims and Private Securities Litigation, 94 Nw U L Rev 567, 570-72 (2000) (noting that a significant number of securities fraud cases are brought by individuals instead of as class actions). Note, however, that if more than fifty individuals file individual claims that have common elements of law or fact, the actions may be treated as a class action, without regard to individual reliance, and if so, under the proposal of this Comment, would be preempted. See 15 USC $\$ \$ 77 \mathrm{p}(\mathrm{f})(2)(\mathrm{A})(\mathrm{ii}), 78 \mathrm{bb}(\mathrm{f})(5)(\mathrm{B})(\mathrm{ii})$.

177 There are strong reasons why states may choose not to allow holding claims. For instance, damages to the holder may be extremely difficult to ascertain because the price at which the plaintiff claims she would have sold may have been artificially inflated by the misrepresentation. See Blue Chip Stamps, 421 US at 742-43 (noting the proof problems associated with claims not meeting the purchase-seller requirement); Levine v Seilon, Inc, 439 F2d 328, 333-34 (2d Cir 1971) (disallowing a holding claim class action in federal court by finding that the holding claim did not implicate a compensable loss because if the misrepresentation had not been made, the price of the stock price would not have been inflated and no gain would have been realized from a sale). Also, the early twentieth century cases allowing holding claims may reflect a different era of securities regulation when securities actions were treated similarly to normal torts between two parties and where the real issue was whether one had a cause of action in matters regarding securities for forbearance. Courts' understanding of securities has changed dramatically, and due to the difficulties in finding actual damages, states that have allowed holding claims in the past may wish to reexamine the practice. See Basic Inc v Levinson, 485 US 224, 243-44 (1988) (noting how much the modern securities market involving millions of shares traded each day differs from the face-to-face transactions in early securities fraud cases and that courts must take note of this fact).

178 Such actions, like all state actions, would be subject to the Uniform Standards Act's stay of discovery if a parallel federal securities claim has also been filed. See note 98 and accompanying text.

179 Derivative suits share the same difficulties of overcompensating plaintiffs' attorneys at the expense of shareholders as do holding claim class actions because both types of suits are primarily driven by the plaintiffs' attorney who will gain the primary direct compensation from a recovery. See Klein and Coffee, Business Organization and Finance at 196-97 (cited in note 31) (discussing how plaintiffs' attorneys use derivative suits as strike suits to gain collusive recoveries 
jured parties without as many worries of strike suits as are present with holding claim class actions. In this way, like in Blue Chip Stamps, disadvantages from preempting holding claim class actions are attenuated by the existence of state law remedies available to injured parties. Therefore, implied preemption of holding claim class actions is not only consistent with the congressional purpose in passing the Uniform Standards Act but is also unlikely to have significant negative deterrent or compensatory effects.

\section{CONCLUSION}

The Uniform Standards Act, in order to combat strike suits, represents a congressional abandonment of the explicit dualism between federal and state private causes of action for securities fraud. Accordingly, in analyzing the validity of holding claim class actions, it is important to examine them in relation to their possible use as strike suits in violation of federal intent rather than solely as being within a state's sovereign powers to regulate securities through private causes of action. Hence, it is essential to focus on the fact that holding claim class actions may be an ideal method for plaintiffs' attorneys to avoid the recent federal statutes and to continue to file strike suits. Only through a finding of implicit preemption of state holding claim class actions can courts ensure that plaintiffs' attorneys will be fully subject to the heightened standards and sanctions of the PSLRA and extend the full advantage of the PSLRA's protections to public companies and their shareholders. Therefore, courts should find holding claim class actions to be implicitly preempted because they obstruct the congressional purpose in passing the Uniform Standards Act.

because corporations pay the plaintiffs' attorney fees if there is a settlement or a judgment). Derivative claims, however, are less likely to overcompensate plaintiffs' attorneys than holding claims because unlike holding claims, which have no built-in procedural hurdles, derivative suits have complex legal hurdles, which may deter strike suits and collusive settlements. See id at 196201 (discussing such procedural devices as the demand rule, the necessity of judicial acquiescence to a proposed settlement, and the use of special litigation committees, which allow a corporation to dismiss an action contrary to the corporation's best interests). Accordingly, derivative suits that survive the procedural hurdles are more likely to compensate injured parties fairly than holding claim class actions.

180 For instance, individual holding actions may not pose as significant a risk of overcompensating plaintiffs' attorneys at the expense of corporate shareholders because damages in individual securities actions are based on the actual damage to the individual plaintiff instead of hypothetical damage from a loss in stock value to the possibly huge class of stockholders. See Yablon, $94 \mathrm{Nw}$ U L Rev at 571 (cited in note 176) (noting that the many individual securities claims ask for damages in the hundreds of thousands to low millions for actual damages to the individual). Accordingly, the facts of an individual case are more likely to allow the corporation to determine whether settlement is a worthwhile option. On the other hand, since the merits of a holding claim class action are hard to determine and because of the expense of discovery, the settlement is less likely to reflect the suit's merits. Individual claims therefore may be more likely accurately to compensate injured shareholders without overcompensating the attorney. 